\title{
Microscale and small-scale temporal dynamics of a coastal planktonic microbial community
}

\author{
Justin R. Seymour ${ }^{1, *}$, Laurent Seuront ${ }^{1,2}$, James G. Mitchell ${ }^{1}$ \\ ${ }^{1}$ Biological Sciences, Flinders University, PO Box 2100, Adelaide, South Australia 5001, Australia \\ ${ }^{2}$ Ecosystem Complexity Research Group, Station Marine de Wimereux, CNRS - UMR 8013 ELICO, \\ Université des Sciences et Technologies de Lille, 28 avenue Foch, 62930 Wimereux, France
}

\begin{abstract}
The temporal dynamics of heterotrophic bacteria and Synechococcus-type cyanobacteria communities were studied in a coastal habitat characterised by strong hydrodynamic variability using $10 \mathrm{~s}$ (microscale) and $30 \mathrm{~min}$ (small-scale) sampling intervals. Flow cytometric analysis allowed for the discrimination of 3 populations of heterotrophic bacteria and the examination of the Synechococcus cell cycle. During the $11 \mathrm{~h}$ small-scale study, 2-fold changes in the total abundance of both the bacterial and Synechococcus communities were observed, and clear temporal patterns in the abundance, activity and cellular state of the 2 populations were evident. Cumulative sum analysis further revealed distinct periods and trends in the temporal dynamics of the bacterial and Synechococcus communities. Shifts in the abundance of all heterotrophic bacterial populations were significantly correlated to turbulent energy dissipation. No such correlation was evident for the Synechococcus population, which instead appeared to follow a diel cell cycle very similar in nature to patterns observed in other environments. In 2 microscale studies, conducted during dissimilar hydrodynamic conditions, approx. 2-fold shifts in the abundance of the bacterial and Synechococcus populations were also observed. Microscale temporal patterns were dominated by localised variability and the existence of hotspots in abundance and activity, although cumulative sum analysis also revealed more general trends, sometimes occurring over periods of several minutes. Fundamentally different patterns, in the extent of temporal variability and coupling between the different microbial populations, were observed between the microscale and small-scale studies, suggesting that intrinsically different mechanisms and responses occurred independently and simultaneously at the different temporal scales. Furthermore, the variability in microbial parameters observed over these short temporal scales indicates the profound importance of microscale and small-scale processes in the ecology of communities of marine microorganisms.
\end{abstract}

KEY WORDS: Heterotrophic bacteria · Synechococcus · Small scale • Microscale · Temporal variability

Resale or republication not permitted without written consent of the publisher

\section{INTRODUCTION}

Communities of marine microorganisms experience variability in physical and biological parameters at spatial and temporal scales spanning 9 orders of magnitude (Dickey 1991). Consequently, the extent and nature of environmental variability can have implications that range from shifting the metabolic state of individual cells to altering the function of entire ecosystems.
Over periods of weeks to months, and across distances of tens of kilometres, variability amongst planktonic communities, often characterised by mesoscale patchiness and the formation and decline of bloom events, occurs in response to large-scale oceanographic features and seasonal oscillations in temperature and nutrients (Ducklow 1984, Denman \& Gargett 1995, Beaugrand et al. 2000, Okubo \& Mitchell 2001). Embedded within these large-scale processes are physical, biological and chemical cycles and rhythms 
that influence communities over the course of hours to days. Populations of autotrophic microorganisms exhibit clear diel patterns in photosynthesis, cell growth and cell division in response to daily light cycles (Jacquet et al. 1998, 2001, 2002, Vaulot \& Marie 1999). Additionally, diel variability in the supply of dissolved organic substrates and grazing intensity promotes daily shifts in the abundance, growth rate and production of heterotrophic bacterioplankton communities (Meyer-Reil et al. 1979, Simon 1994, Torréton et al. 1994, Shiah \& Ducklow 1995, Gasol et al. 1998, Hagström et al. 2001).

At even smaller scales, microscale processes, occurring across distances of micrometres to centimetres (Mitchell et al. 1985, Azam 1998, Kiørboe \& Jackson 2001), often over time frames of just seconds to minutes (Bratbak et al. 1996, Blackburn et al. 1998, Seuront et al. 2002), are also predicted to influence the behaviour and ecology of marine microorganisms. Microscale patches of dissolved organic and inorganic substrates may provide important, albeit ephemeral, growth habitats for heterotrophic (Mitchell et al. 1985, Blackburn et al. 1997, 1998, Blackburn \& Fenchel 1999) and autotrophic microorganisms (Lehman \& Scavia 1982, Seuront et al. 2002), while suspended and sinking particulate matter also provides unique microhabitats of increased nutrients for attached (Bidle \& Azam 1999, Grossart et al. 2003) and free-living microorganisms (Kiørboe \& Jackson 2001). In addition, physical processes are likely to affect planktonic life at a variety of scales (Marrasé et al. 1997), and turbulence has repeatedly been shown to control the extent of variability observed in the small-scale distributions of nutrients (Seuront et al. 2002), bacteria (Seymour et al. 2000, Andreatta et al. 2004) and phytoplankton (Seuront et al. 1999, Seuront \& Schmitt 2001, 2003)

Given that the mechanisms responsible for developing and maintaining heterogeneity amongst aquatic microbial communities vary according to scale, the extent and nature of biological variability will also differ with scale. Small- and microscale variability in microbial parameters can often be as great as, or greater than, the variability observed at the ocean's largest scales. Diel changes amongst autotrophic communities are often larger than the variability observed over weeks to months (Vaulot \& Marie 1999). Similarly, whereas bulk abundances of heterotrophic bacteria remain relatively stable across a broad range of aquatic environments, rarely varying by more than 3 orders of magnitude (del Giorgio \& Scarborough 1995), bacteria associated with microscale features, such as organic aggregates, can be up to 5 orders of magnitude more concentrated than in the surrounding water (Alldredge et al. 1986).

The nature and pattern of variability in microbiological parameters will also differ with scale. Over large distances and long time periods, spatial and temporal variability is characterised by palpable incremental changes and oscillations that remain relatively coherent and are often highly predictable (e.g. diel, tidal or seasonal oscillations). Microscale processes, however, are generally more intermittent, and are likely to generate 'peaky' temporal and spatial distributions, characterised by the existence of discrete 'hotspots' and 'coldspots' (Bratbak et al. 1996, Azam 1998, Seymour et al. 2000, 2004).

To understand the relative importance of any one or suite of the physical and biological factors that influence the ecology and dynamics of communities of aquatic microorganisms, it is first necessary to appreciate the scales at which the greatest levels of change occur. Multi-scale comparative studies allow for this determination, and previous studies have compared large-scale and diel dynamics within a single ecosystem or habitat (Wikner \& Hagström 1991, Shiah \& Ducklow 1995) and have widely illustrated the importance of processes occurring over the shorter time scales (Shiah \& Ducklow 1995, Jacquet et al. 2002). However, despite an increasing awareness of the relevance of microscale processes in marine microbial ecology (Azam 1998, Seuront 2001), to our knowledge comparisons between small-scale (hours) and microscale (seconds-minutes) temporal dynamics have yet to be made.

In this context, we have studied a coastal microbial community and compared the degree and nature of temporal variability in biological parameters occurring during the daylight hours of a single day by sampling at a small-scale resolution of $30 \mathrm{~min}$, to the microscale community dynamics observed by sampling at a resolution of $10 \mathrm{~s}$. Inherently different mechanistic processes and responses are expected to operate at these different temporal scales, but we demonstrate that the absolute extent of variation in microbial abundance and cellular parameters (e.g. cell size, DNA content) were comparable between scales; however, the nature and patterns of the observed variability were somewhat dissimilar.

\section{MATERIALS AND METHODS}

Study site. Sampling was conducted over an $11 \mathrm{~h}$ period from 08:00 to 19:00 h on 31 January 2003. Samples were collected from the end of a coastal jetty, situated within a lagoon on the shoreward side of a rocky coastal reef at Pt. Noarlunga $\left(35^{\circ} 09^{\prime} \mathrm{S}\right.$, $138^{\circ} 28^{\prime}$ E), within St. Vincent Gulf in South Australia. The sampling point was situated approximately $150 \mathrm{~m}$ from the shoreline of a protected coastal beach and approximately $7 \mathrm{~m}$ from the periodically tidally submerged Pt. Noarlunga reef. 
The Pt. Noarlunga reef is a flat-topped rocky reef that supports an abundant macroalgae community generally dominated by the kelp Ecklonia radiata (Cheshire et al. 1999). The environment to the shoreward side of the reef, where samples were collected, is characterised by highly variable hydrodynamic conditions that are strongly tide-dependent and can vary considerably over the course of a day. During high tide, wave surges wash over the reef and high levels of turbulence are experienced within the lagoon. During low tide, however, the reef provides a natural barrier between the water masses on the seaward and shoreward sides of the reef, and there is little or no water exchange across the reef. The depth of the water column at the sampling site varies from approximately 8 to $10 \mathrm{~m}$ in depth, depending upon the stage of the tidal cycle.

Characterisation of the physical environment. Salinity and temperature were measured every $30 \mathrm{~min}$ using a Hydrolab DataSonde 4a. Hydrodynamic conditions were also measured at 30 min intervals using a Sontek Acoustic Doppler Velocimeter (ADV), with flow data accumulated onto a laptop computer for at least $3 \mathrm{~min}$, at a sampling rate of $25 \mathrm{~Hz}$, during each measurement. Velocity fields in 3 dimensions $\left(u_{x}, u_{y}, u_{z}\right)$ were computed using WinADV software (Tony Wahl, US Bureau of Reclamation), and turbulent kinetic energy dissipation rates $(\varepsilon)$ were calculated using the following derivation.

Following the Reynolds decomposition (Tennekes \& Lumley 1972), a 1-dimensional velocity field $\left(u, \mathrm{~m} \mathrm{~s}^{-1}\right)$ was decomposed into an average $\left(U, \mathrm{~m} \mathrm{~s}^{-1}\right)$ and an instantaneous, fluctuating turbulent component $\left(u^{\prime}\right.$, $\mathrm{m} \mathrm{s}^{-1}$ ) as:

$$
u=U+u^{\prime}
$$

where the average component $U$ represents the longterm structured variation, such as a mean velocity field, a tidal current or wave motion.

Taking into account the noise related to the measurement device and/or the quantity and quality of suspended particles that may contaminate the observed turbulent signal $u$, the Reynolds decomposition must be rewritten as:

$$
u=U+u^{\prime}+u_{\text {noise }}
$$

where $u_{\text {noise }}\left(\mathrm{m} \mathrm{s}^{-1}\right)$ is the velocity component associated with noise. Here we estimated $u_{\text {noise }}$ by placing the ADV probe within a $1.5 \mathrm{~m}$ high, $40 \mathrm{~cm}$ diameter plastic cylinder filled with seawater from the sampling site. It was ensured using the Sontek ADVField Software (Version 2.4a) that no boundary (associated with the walls of the cylinder) was detected by the probe, and after being allowed to settle for $10 \mathrm{~min}$, data were accumulated for 5 min and analysed as described above.
Then, squaring and time averaging Eq. (2) leads to:

$$
\left\langle u^{2}\right\rangle=\left\langle\left(U+u^{\prime}+u_{\text {noise }}\right)^{2}\right\rangle
$$

and

$$
\begin{aligned}
\left\langle u^{2}\right\rangle= & \left\langle U^{2}\right\rangle+\left\langle\left(u^{\prime}\right)^{2}\right\rangle+\left\langle u_{\text {noise }}^{2}\right\rangle+\left\langle 2 U u^{\prime}\right\rangle \\
& +\left\langle 2 U u_{\text {noise }}\right\rangle+\left\langle 2 u^{\prime} u_{\text {noise }}\right\rangle
\end{aligned}
$$

Under the assumption that the 3 velocity components $U, u^{\prime}$ and $u_{\text {noise }}$ are uncorrelated, Eq. (4) is equivalently written as:

$$
u_{\mathrm{rms}}^{2}=\left\langle u^{2}\right\rangle-U^{2}-\left\langle u_{\text {noise }}^{2}\right\rangle
$$

where $u_{\mathrm{rms}}\left(\mathrm{m} \mathrm{s}^{-1}\right), u_{\mathrm{rms}}=\sqrt{\left\langle\left(u^{\prime}\right)^{2}\right\rangle}$, is the root-meansquare turbulent velocity of the 1-dimensional velocity field, and $U^{2}=\left\langle U^{2}\right\rangle$.

Now, the 3-dimensional root-mean-square turbulent velocity $W_{\mathrm{rms}}\left(\mathrm{m} \mathrm{s}^{-1}\right)$ is estimated as (Tennekes \& Lumley 1972):

$$
w_{\mathrm{rms}}^{2}=\frac{1}{3}\left(u_{x}^{2}+u_{y}^{2}+u_{z}^{2}\right)
$$

where $u_{x}, u_{y}$ and $u_{z}$ are the 2 horizontal and the vertical velocity components, respectively. The turbulent kinetic energy dissipation rate $\varepsilon\left(\mathrm{m}^{2} \mathrm{~s}^{-3}\right)$ is subsequently estimated as (Taylor 1938):

$$
\varepsilon=\mathrm{k}\left(W_{\mathrm{rms}}^{3} / L\right)
$$

where $\mathrm{k}$ is a constant $(\mathrm{k}=1$, Wolk et al. 2001) and $L$ the integral length scale of turbulence, i.e. a characteristic length scale representing the larger turbulent vortexes. Here $L$ was assigned as $8 \mathrm{~m}$, which is the approximate size of the largest eddies in the sampling system, which in this case is the depth of the water column at the sampling point.

Small-scale temporal dynamics of the planktonic microbial community. The small-scale temporal dynamics of the microbial community inhabiting the Pt. Noarlunga site were examined over the course of an $11 \mathrm{~h}$ daylight period at a sampling resolution of $30 \mathrm{~min}$. At each sampling interval, triplicate $400 \mu \mathrm{l}$ water samples were collected from $5 \mathrm{~cm}$ below the water surface using a micropipette. Samples were transferred to sterile $2 \mathrm{ml}$ cryovials and immediately incubated with $2 \%$ (final concentration) paraformaldehyde for $20 \mathrm{~min}$ before being quick-frozen in liquid nitrogen and then stored at $-80^{\circ} \mathrm{C}$.

Microscale temporal dynamics of the planktonic microbial community. The microscale temporal dynamics of the Pt. Noarlunga bacterial community were investigated during 2 independent time series. Microscale Study 1 (M1) was conducted at 13:30 h during mid-low tide and relatively calm hydrodynamic conditions. Microscale Study 2 (M2) was conducted at 16:30 h during mid-high tide and a period of strong turbulence. In each case, $400 \mu$ l samples were collected 
from $5 \mathrm{~cm}$ below the water surface using a micropipette, at a temporal resolution of $10 \mathrm{~s}$, for a period of $16.5 \mathrm{~min}$. Samples were fixed and frozen as described above.

Flow cytometric analysis of samples. Flow cytometry (FCM) was used to identify and enumerate heterotrophic bacteria and Synechococcus-type cyanobacteria within both the microscale and small-scale time-series samples. Prior to flow cytometric analysis, samples were stained with SYBR-I Green solution (1:10 000 dilution; Molecular Probes) and incubated in the dark for 15 min (Marie et al. 1997, 1999). Fluorescent beads $1 \mu \mathrm{m}$ in diameter (Molecular Probes) were added to samples in a final concentration of approx. $10^{5}$ beads $\mathrm{ml}^{-1}$ (Gasol \& del Giorgio 2000), and all measured cytometry parameters were normalised to bead concentration and fluorescence.

Flow cytometric analysis was conducted using a Becton-Dickinson FACScan flow cytometer, equipped with an air-cooled argon laser (15 mW, $488 \mathrm{~nm})$ with phosphate buffered saline (PBS) solution employed as a sheath fluid. Acquisition was run until at least 50 to $100 \mu \mathrm{l}$ of sample was analysed at a rate of approx. $40 \mu \mathrm{l}$ $\mathrm{min}^{-1}$. For each sample, forward-angle light scatter (FSC), side-angle light scatter (SSC), green (SYBR-I) fluorescence, red (chlorophyll) fluorescence, and orange (phycoerythrin) fluorescence were acquired. Discrete subpopulations of heterotrophic bacteria were identified according to variations in green fluorescence and side scatter (Marie et al. 1997, Gasol et al. 1999), while Synechococcus populations could be clearly defined according to higher levels of orange and red fluorescence than the heterotrophic community (Marie et al. 1997, Jacquet et al. 1998). Data for individual subsamples were collected in list-mode files and analysed using CYTOWIN flow cytometry analysis software (Vaulot 1989), and cytograms were drawn using Win Midi 2.8 software (Joseph Trotter).

Statistical analysis. As the temporal distributions of the microbial community were significantly nonnormal (Kolmogorov-Smirnov test, p < 0.05) and the number of measurements was low ( $\mathrm{n}=23$ ), nonparametric statistics were employed throughout this work. Correlations between different microbial variables were investigated using Kendall's coefficient of rank correlation, $\tau$ (Kendall \& Stuart 1966). Kendall's coefficient of correlation was used in preference to Spearman's coefficient of correlation $\rho$ here because Spearman's $\rho$ gives greater weight to pairs of ranks that are further apart, while Kendall's $\tau$ weights each disagreement in rank equally (see Sokal \& Rohlf 1995).

Trends in time-series data, including time, intensity and duration of changes in the values of a given parameter, were investigated using the cumulative sums method (Ibañez et al. 1993). The cumulative sums method has been applied to investigate patterns in phytoplankton, zooplankton and hydroclimatic time series data (Le Fevre-Lehoerff et al. 1995, Nicholls 1997, Beaugrand et al. 2000) and has been proposed as a robust method for environmental time-series monitoring (Manly \& Mackenzie 2000). Cumulative sum analysis consists of subtracting a reference value $\mathrm{k}$ (usually the mean of the series) from each data point within a chronological series of data $x_{t}$ sampled at time $t$ (for $t$ between 1 and $\mathrm{n}$ ) and then adding the residuals successively to form a cumulative function (Ibañez et al. 1993, Le Fevre-Lehoerff et al. 1995):

$$
S_{p}=\sum X_{i}-p \mathrm{k}
$$

Specifically, in this study, $\mathrm{k}$ was assigned as the mean value of the time series and then subtracted from each data point from the time series separated by a time interval of $30 \mathrm{~min}$ (small-scale study) or $10 \mathrm{~s}$ (microscale study). The residual values were then added successively to form cumulative sum plots.

In cumulative sum plots, when successive negative residuals occur, a decreasing slope is created, whereas successive positive residuals create an increasing slope (the value of the slope is proportional to the deviation from the mean). Values similar to the mean $(\mathrm{k})$ exhibit no slope. Therefore, this technique allows for the graphical representation of distinct periods in timeseries data. Furthermore, the cumulative sum function is very sensitive to changes of the local mean within time-series data sets (Ibañez et al. 1993), and trends and cycles, which may not be immediately apparent in raw time-series data, can be identified graphically by shifts and inflection points in the cumulative sum series. To gain an indication of the strength of the relationship between the cumulative sum plots from different populations, Kendall's coefficient of rank correlation was calculated (see Le Fevre-Lehoerff et al. 1995 for a discussion on calculating correlations for autocorrelated cumulative sums data).

\section{RESULTS}

\section{Environmental conditions}

During the study period, high tide occurred prior to the start of sampling at 04:00 $\mathrm{h}$ and then again at 17:30 h, while low tide occurred at 11:30 h. During mid-high tide (08:30 to $10: 00 \mathrm{~h}$ and $15: 30$ to $19: 00 \mathrm{~h}$ ) free exchange of water occurred over the Pt. Noarlunga reef, with $\sim 1 \mathrm{~m}$ waves breaking over the submerged reef, and during these times the highest levels of turbulent kinetic energy $\left(\sim 20 \mathrm{~cm}^{2} \mathrm{~s}^{-3}\right)$ were observed (Fig. 1). Levels of turbulent kinetic energy reached maximum levels at the end of the measure- 


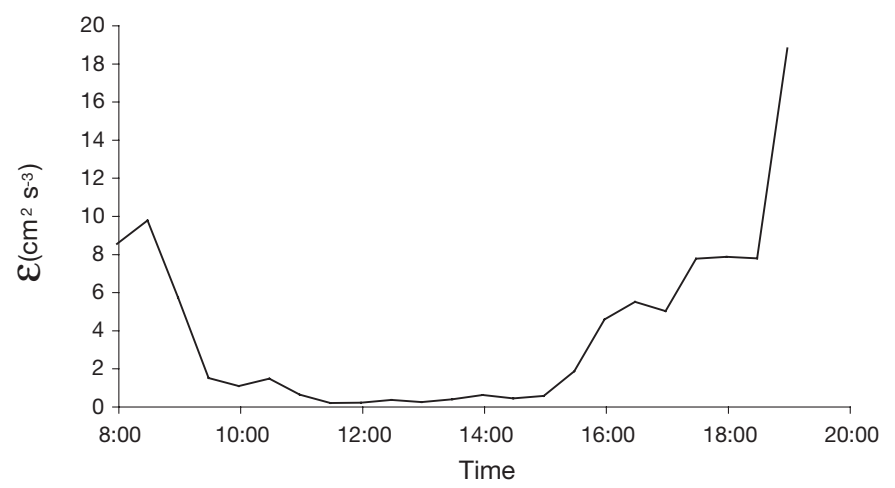

Fig. 1. Turbulent kinetic energy dissipation rates at the Pt. Noarlunga site calculated from measurements made with a Sontek ADV during the small-scale study

ment period when the low tide coincided with a moderate $\left(40 \mathrm{~km} \mathrm{~h}^{-1}\right)$ on-shore south-westerly wind, which led to an increase in the size and frequency of the waves breaking over the reef and into the lagoon. During mid-low tide (between 10:30 and 15:00 h) the reef was totally exposed, preventing water exchange between the open waters of St. Vincent's Gulf and the shoreward side of the reef, and levels of turbulent kinetic energy were consequently the lowest during this time $\left(\sim 0.1 \mathrm{~cm}^{2} \mathrm{~s}^{-3}\right.$, Fig. 1).

Mean surface temperature and salinity levels were $21 \pm 0.3^{\circ} \mathrm{C}$ and $37.75 \pm 0.1$, respectively, and remained relatively homogenous over the course of the sampling period. Depth profiles of these parameters measured at low, mid and high tide also indicated that the water column at the sampling site remained well mixed during the course of the study (data not presented).

\section{Flow cytometric identification of microbial populations}

Flow cytometry allowed for the discrimination of 3 populations of heterotrophic bacteria and a population of the autotrophic cyanobacterium Synechococcus within samples (Fig. 2). The bacterial community exhibited clear differentiation between high DNA (HDNA) and low DNA (LDNA) groups of bacteria (Gasol et al. 1999). A 2.5-fold difference in green fluorescence, applied here as a measure of DNA content (Marie et al. 1997), was observed between the HDNA and LDNA groups. In accordance with the observations of numerous previous studies showing that HDNA bacteria represent active cells, while LDNA bacteria represent dead or dormant cells (Li et al. 1995, Jellett et al. 1996, Gasol et al. 1999, Lebaron et al. 2001, 2002, Servais et al. 2003), we applied the percentage of HDNA bacteria as a measure of bacterial single cell activity (Gasol et al. 1999). Within the HDNA population, further differentiation between groups differing in SSC, and corresponding to the BII and BIII populations previously described by Marie et al. (1997), was observed. These populations were defined here as HDNA(I) and HDNA(II) groups (Fig. 2A). A population of Synechococcus-type cyanobacteria could also be differentiated from the heterotrophic bacteria according to higher levels of red and orange fluorescence (Jacquet et al. 1998) (Fig. 2B).

\section{Small-scale temporal variability in microbial populations}

Mean concentrations of heterotrophic bacteria were $8.6 \times 10^{5}$ cells $\mathrm{ml}^{-1}$ during the study period. Over the course of the $11 \mathrm{~h}$ study, total bacterial concentrations
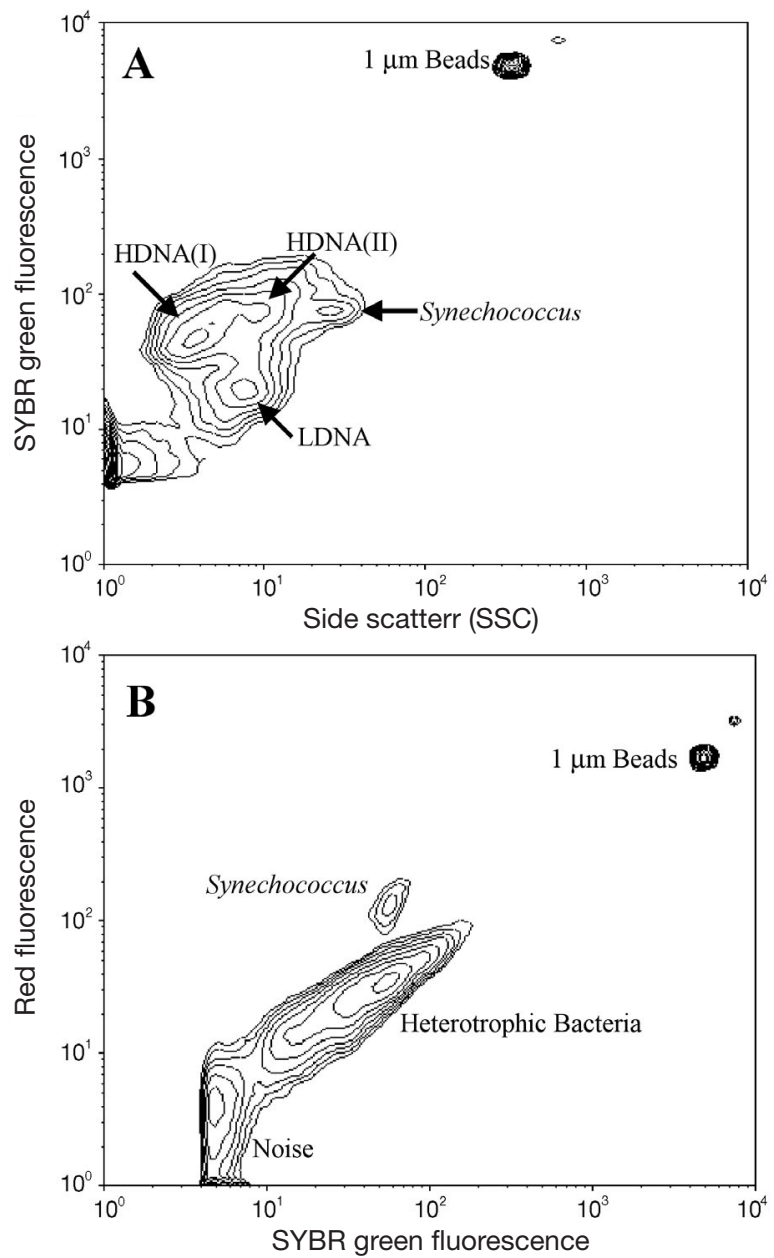

Fig. 2. Flow cytometric characterisation of Synechococcus and heterotrophic bacterioplankton populations. (A) Bacterial subpopulations separated according to differing nucleic acid content (SYBR green fluorescence) and cell size (SSC); (B) Synechococcus population discriminated from heterotrophic bacteria by higher red fluorescence levels 

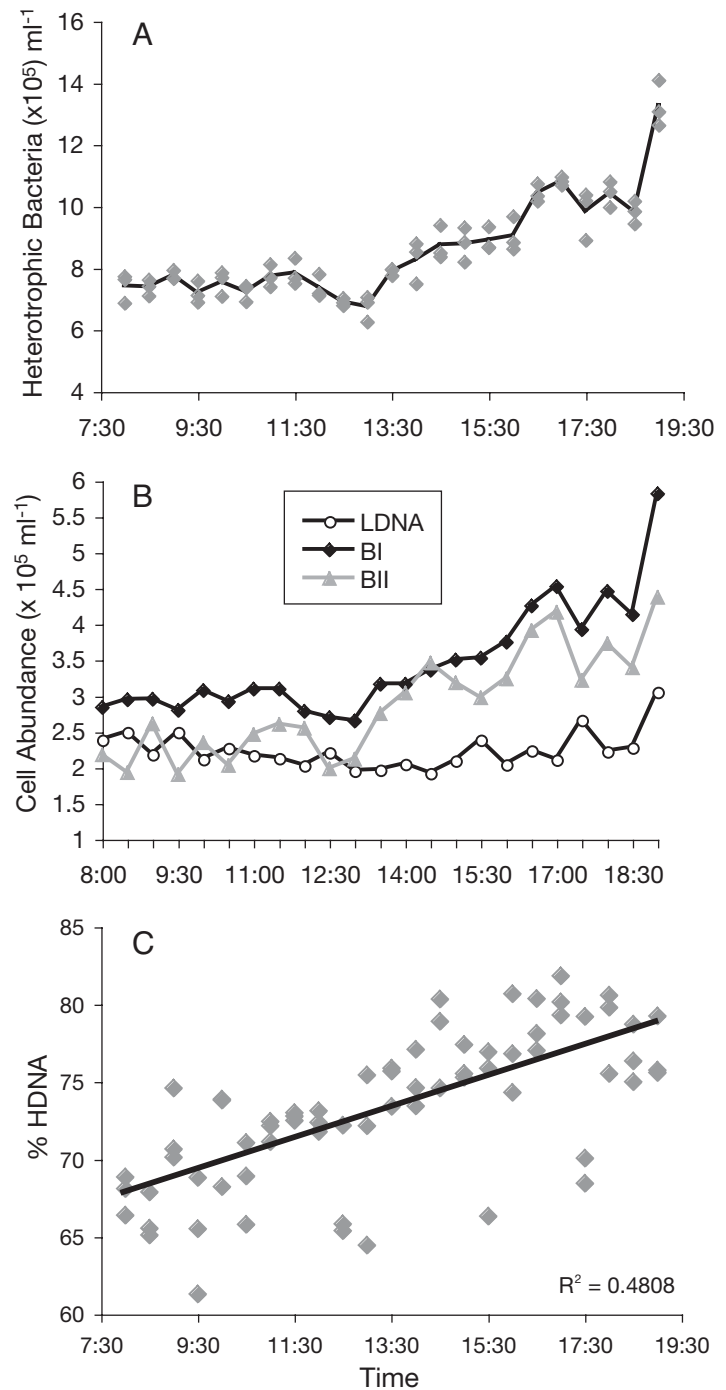

Fig. 3. Dynamics of the heterotrophic bacterial community over the course of the small-scale temporal study. (A) Total bacterial abundance. Grey points: individual triplicate samples taken at each sampling interval; solid line: mean of triplicates. (B) Abundance of flow cytometrically defined subpopulations of bacteria. (C) Percentage of high DNA (HDNA) cells. Trend line: linear regression through all triplicate subsamples varied by approximately 2-fold, with maximum concentrations observed at the end of the sampling period. Total bacterial abundance remained relatively constant from morning until noon, and then showed a general trend of increasing concentration from noon until dusk (Fig. 3A). This was confirmed by the pattern exhibited by the cumulative sum of bacterial abundance, where a U-shape trend and 2 distinct periods were clearly evident (Fig. 4A). An inflection point is apparent at 14:00 h, with a negative slope, indicative of successive values lower than the mean, observed before this time, and a positive slope, indicative of successive values higher than the mean, observed after this point. The abundance of the bacterial community was significantly correlated to turbulent energy dissipation levels measured during the sampling period (Table 1). Furthermore, the cumulative sum of the heterotrophic bacteria exhibited a significant level of correlation to the cumulative sum of the turbulent energy dissipation $(\tau=0.518, \mathrm{p}<0.01)$.

Within the heterotrophic bacterial community the HDNA(I) and HDNA(II) populations displayed similar trends in abundance that mirrored the changes in abundance of the total bacterial community, with a 2.3and 2.4-fold change in concentration exhibited by the HDNA(I) and HDNA(II) populations respectively (Fig. 3B). The HDNA(I) and HDNA(II) populations were highly correlated to the distribution of the total bacterial community and to each other (Table 1). The cumulative sum plot of the combined HDNA populations exhibited a U-shape pattern, with 2 distinct periods apparent, and a clear inflection point at approximately 14:00 h present (Fig. 4D). The cumulative sum of the HDNA populations was correlated to the cumulative sums of the total bacterial community $(\tau=0.934$, $\mathrm{p}<0.01)$ and turbulent energy dissipation $(\tau=0.660$, $\mathrm{p}<0.01)$.

The LDNA population exhibited a lower degree of variability than the HDNA populations, with only a 1.5-fold change in abundance observed during the sampling period (Fig. 3B). The temporal patterns

Table 1. Correlation values for microbial parameters from the small-scale time-series study. All values = Kendall's coefficient of rank correlation, $\tau$. Significance: ${ }^{*} 0.05$ level, ${ }^{* *} 0.01$ level. Synech $=$ Synechococcus population; FSC $=$ cellular forward scatter; FL2 = orange (phycoerythrin) fluorescence

\begin{tabular}{|lccccccc|}
\hline & Turbulence & LDNA & HDNA(I) & HDNA(II) & Total bacteria $\%$ HDNA & Synech & Synech FSC \\
\hline Turbulence & & & & & & & \\
LDNA & $0.534^{* *}$ & & & & & \\
HDNA(I) & $0.366^{*}$ & 0.067 & & & & \\
HDNA(II) & $0.320^{*}$ & -0.067 & $0.787^{* *}$ & & & \\
Total bacteria & $0.352^{*}$ & 0.075 & $0.945^{* *}$ & $0.826^{* *}$ & & \\
\%HDNA & 0.075 & -0.233 & $0.700^{* *}$ & $0.834^{* *}$ & $0.692^{* *}$ & & \\
Synech & 0.209 & $0.391^{* *}$ & -0.178 & $-0.296^{*}$ & -0.170 & $-0.383^{*}$ & $-0.676^{* *}$ \\
Synech FSC & -0.091 & -0.162 & $0.312^{*}$ & $0.368^{*}$ & $0.320^{*}$ & $0.407^{* *}$ & $-0.352^{*}$ \\
Synech FL2 & -0.237 & $-0.375^{*}$ & 0.004 & 0.047 & -0.02 & 0.099 & 0.170 \\
\hline
\end{tabular}



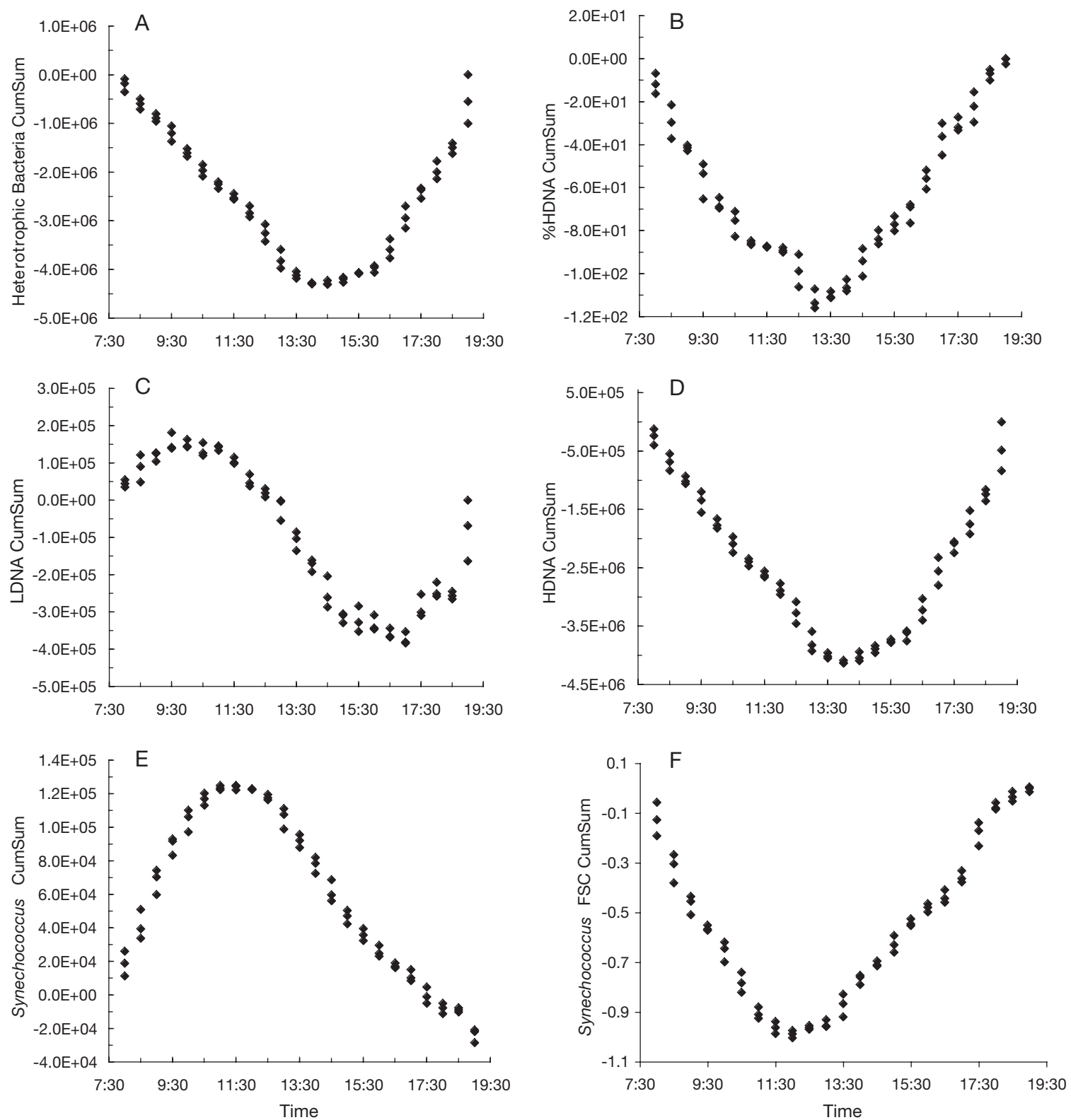

Fig. 4. Cumulative sum plots for small-scale temporal study data. (A) Total bacteria, (B) \% high DNA (HDNA), (C) low DNA (LDNA), (D) HDNA, (E) Synechococcus cell counts, (F) Synechococcus mean forward-angle light scatter (FSC)

exhibited by the LDNA population were not significantly correlated to either the HDNA(I) or (II) populations or to the total bacterial population (Table 1) and exhibited an entirely different cumulative sum pattern to the HDNA and total bacteria populations (Fig. 4C). However, the LDNA population was significantly correlated to turbulent energy dissipation rates (Table 1).

The changes in concentration of the HDNA(I) and (II) populations caused a shift in the percentage of HDNA cells during the course of the sampling period. The mean percentage of HDNA cells was $73 \%$, and a general trend of increasing HDNA percentage was observed over the course of the day, varying from 65 to $81 \%$ (Fig. 3C). In a cumulative sum plot, the percentage of HDNA cells expressed a similar U-shape pattern to that observed for both the total bacteria and HDNA populations (Fig. 4B). No correlation was observed between the percentage of HDNA cells and turbulent energy dissipation rates (Table 1).

Mean Synechococcus concentrations were $2 \times 10^{4}$ cells $\mathrm{ml}^{-1}$ but also varied by approximately 2 -fold during the course of the study. A clear decrease in the concentration of Synechococcus from a maximum of $3 \times$ $10^{4}$ cells ml ${ }^{-1}$ at $08: 30 \mathrm{~h}$ to a minimum of $1.5 \times 10^{4}$ cells 

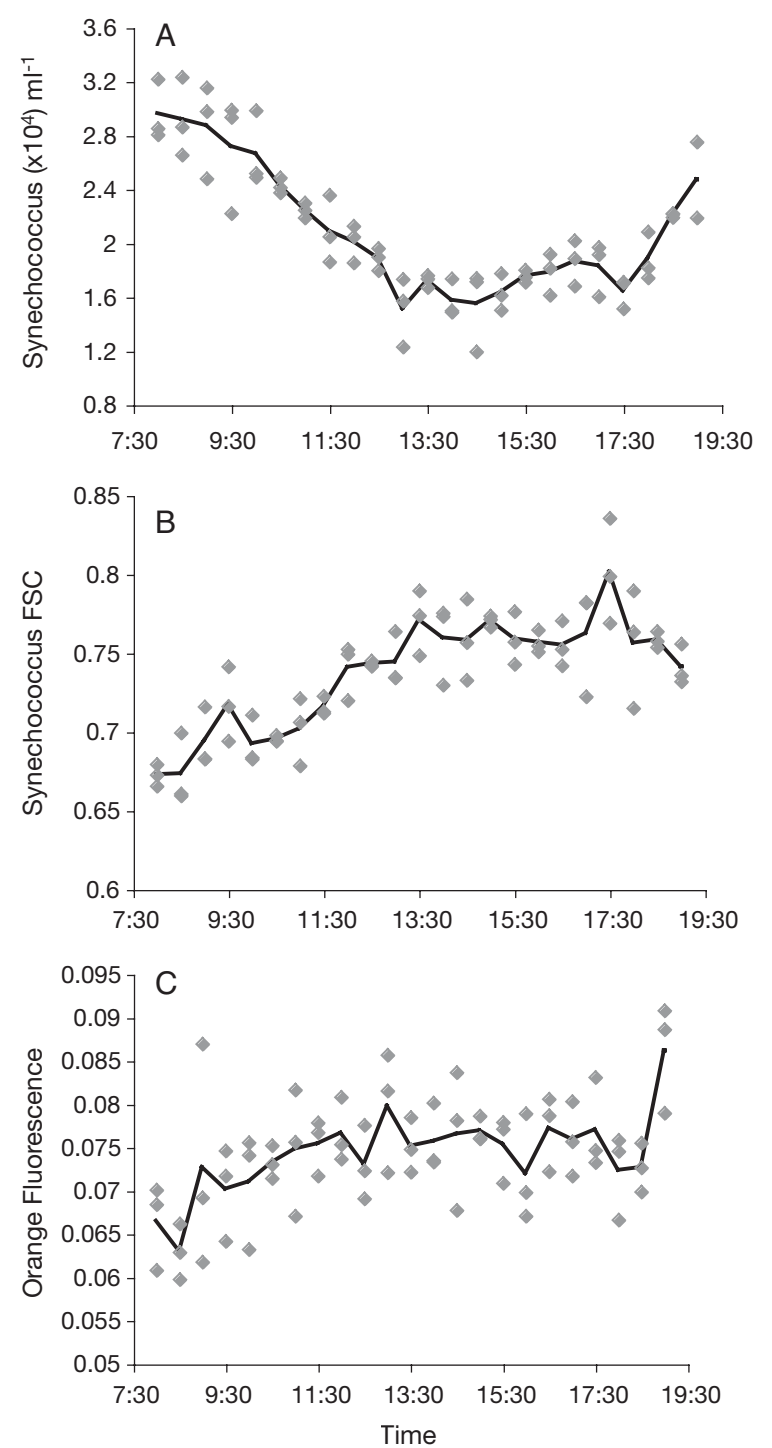

Fig. 5. Dynamics of the Synechococcus population over the course of the small-scale temporal study. (A) Total abundance. (B) Cellular forward scatter (FSC). (C) Mean cellular orange fluorescence. Grey points: individual triplicate samples taken at each sampling interval; solid line: mean of triplicates

$\mathrm{ml}^{-1}$ at 13:00 h was observed (Fig. 5A). While no clear trends in either the mean orange phycoerythrin fluorescence or the red chlorophyll fluorescence of Synechococcus cells were observed during the study period (Fig. 5C), forward-angle light scatter (FSC) (indicative of cell size) was shown to exhibit an opposing trend to cell counts, with maximum values experienced in midafternoon and minimum values in early morning (Fig. 5B). Statistically significant negative correlations were observed between Synechococcus cell concentration and mean cell forward scatter and orange fluorescence (Table 1). No correlation between the Synechococcus population and the heterotrophic bacterial population or turbulent energy dissipation rates were observed (Table 1).

Where temporal patterns were expressed as cumulative sum plots, the Synechococcus population exhibited a dissimilar pattern to the bacterial populations (Fig. 4E). In cumulative sum plots of Synechococcus mean FSC, a pattern directly inverse to that of Synechococcus cell counts was observed (Fig. 4F), and a significant negative correlation $(\tau=-0.790, \mathrm{p}<0.01)$ was calculated between the cumulative sums of Synechococcus cell counts and Synechococcus FSC.

\section{Microscale variability in microbial populations}

As a consequence of being conducted at different times of day, mean microbial abundances varied slightly between the 2 microscale studies. In Microscale Study 1 (M1), mean bacteria and Synechococcus concentrations were $8.6 \times 10^{5}$ and $1.6 \times 10^{4} \mathrm{ml}^{-1}$, respectively, and the mean percentage of HDNA cells was $77 \%$. Alternatively, in Microscale Study 2 (M2), mean bacteria and Synechococcus concentrations were $1.1 \times 10^{6}$ and $1.7 \times 10^{4} \mathrm{ml}^{-1}$, respectively, and the mean percentage of HDNA cells was $79 \%$. Additionally, due to equipment failure, M1 was conducted over only $14.5 \mathrm{~min}$, rather than $16.5 \mathrm{~min}$.

M1 was conducted at mid-low tide and during relatively calm conditions, where turbulent kinetic energy dissipation rates were $0.31 \mathrm{~cm}^{2} \mathrm{~s}^{-3}$. M2 was alternatively conducted during a period of moderate-high turbulence $\left(5.4 \mathrm{~cm}^{2} \mathrm{~s}^{-3}\right)$ during mid-high tide. Examination of the 3-dimensional velocity components measured using the ADV showed that during the study period flow was dominated by water movement over the Pt. Noarlunga reef in a shoreward direction. The mean water velocity in this direction was $6.1 \mathrm{~cm} \mathrm{~s}^{-1}$ and $22.6 \mathrm{~cm} \mathrm{~s}^{-1}$ for M1 and M2, respectively. By applying Taylor's hypothesis of frozen turbulence (Taylor 1938), which states that temporal and spatial averages of time $(t)$ and length scale ( $l$ ) can be related by a constant velocity $\mathrm{V}$ as $l=\mathrm{V} \times t$, we estimated the spatial scales associated with the sampling procedure as $61 \mathrm{~cm}$ and $2.3 \mathrm{~m}$ for $\mathrm{M} 1$ and $\mathrm{M} 2$, respectively.

In both microscale studies, distributions were characterised by localised variability and the presence of 'hotspots' and 'coldspots' (Fig. 6A). While the nature of the variability observed was different between the small-scale and microscale studies (see Figs. 3, 5 \& Fig. 6), the absolute changes in abundance were highly comparable between studies. The bacterial community exhibited a 1.8- and 1.9-fold change in total abundance in the M1 and M2 studies, respectively, and spanned a similar range of concentrations over the $16 \mathrm{~min}$ sampling periods to the changes 

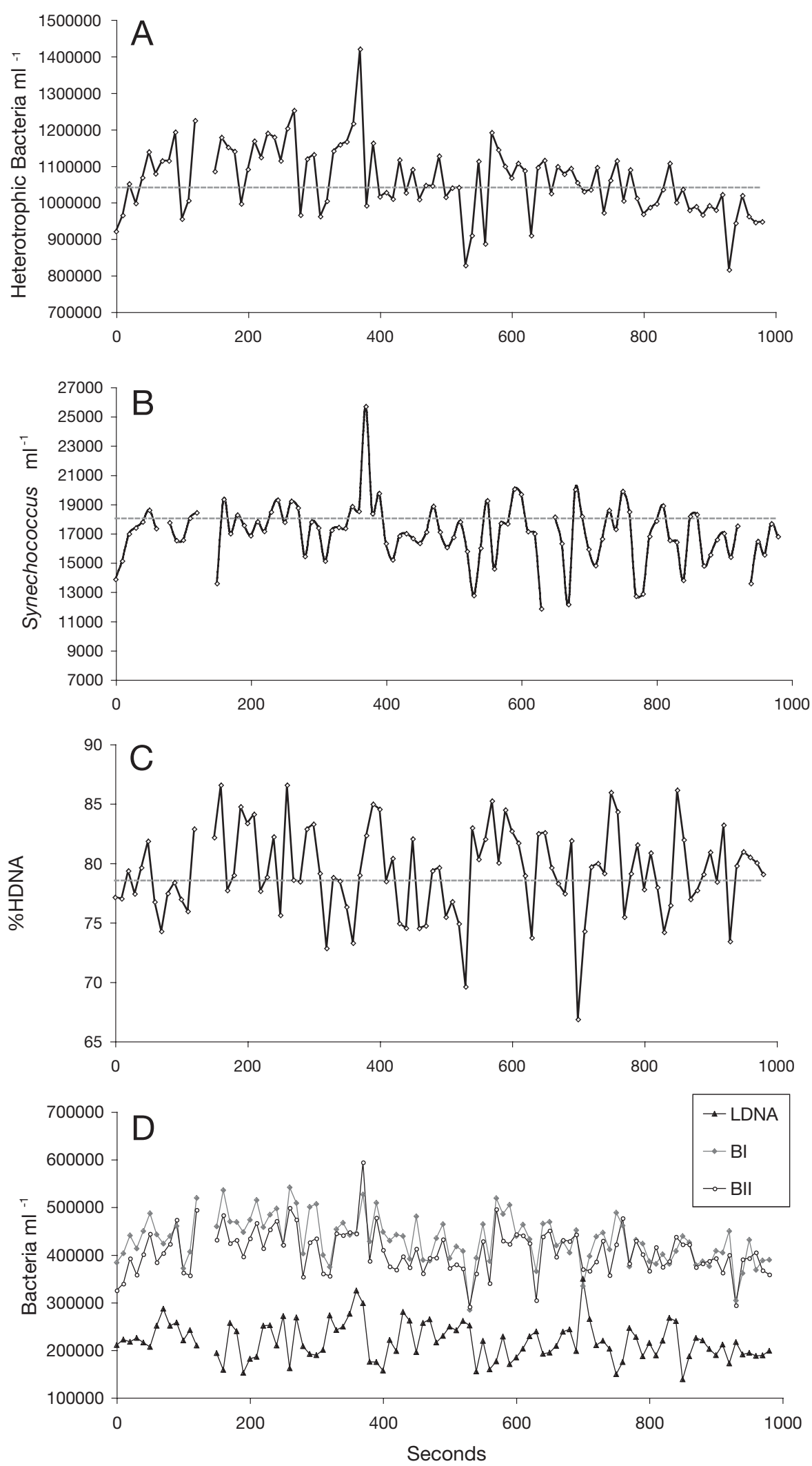

Fig. 6. Microscale temporal time series M2; 10 s resolution, 16 min duration. (A) Total heterotrophic bacteria (dotted grey line: mean bacterial abundance at corresponding time in small-scale study, i.e. 16:30 h), (B) Synechococcus cell counts (dotted grey line: mean Synechococcus abundance at corresponding time in small-scale study, i.e. 16:30 h), (C) \% high DNA (HDNA) (dotted grey line: mean \% HDNA at corresponding time in small-scale study, i.e. 16:30 h), (D) flow cytometrically defined subpopulations of heterotrophic bacteria 
observed over the $11 \mathrm{~h}$ period. Each of the bacterial subpopulations was also found to span a comparable range of concentrations to those observed over the $11 \mathrm{~h}$ sampling period. However, whereas the LDNA group was the least variable subpopulation during the $11 \mathrm{~h}$ study period, in the case of both microscale studies, this group represented the most variable of the bacterial subpopulations, with a change in concentration of 2.5-fold observed in both the M1 and M2 studies. As was observed at the larger sampling scale, the LDNA population was not found to be positively correlated to either of the HDNA populations (Tables $2 \& 3$ ), while the HDNA(I) and (II) populations were correlated to each other and to the distribution of the total bacterial community in both microscale studies (Tables $2 \& 3$ ). Changes in the percentage of HDNA cells exhibited slightly larger degrees of variability in both of the 16 min microscale studies (M1: 67 to $85 \%$, M2: 67 to $86 \%)$ than were observed during the $11 \mathrm{~h}$ study period (65 to $81 \%$ ) (Fig. 6).

The Synechococcus population exhibited an equivalent degree of variability during the 16 min microscale studies to that observed during the $11 \mathrm{~h}$ study, with a 2.0- and 2.2-fold change in total abundance observed in the M1 and M2 studies, respectively. Like the heterotrophic bacterial populations, the variability expressed at the microscale was in the form of localised hotspots and coldspots in abundance

Table 2. Correlation values for microbial parameters from Microscale Time Series 1 (M1). All values = Kendall's coefficient of rank correlation, $\tau$. ${ }^{*}$ : significance at the 0.05 level, $^{* *}$ : significance at the 0.01 level. LDNA: low DNA, HDNA: high DNA

\begin{tabular}{|lcllll|}
\hline & LDNA & HDNA(I) & HDNA(II) & Total bacteria \%HDNA \\
\hline LDNA & & & & & \\
HDNA(I) & -0.023 & & & & \\
HDNA(II) & -0.067 & $0.651^{* *}$ & & & \\
Total Bacteria & $0.197^{* *}$ & $0.719^{* *}$ & $0.665^{* *}$ & & \\
\%HDNA & $-0.657^{* *}$ & $0.355^{* *}$ & $0.393^{* *}$ & $0.146^{*}$ & \\
Synechococcus & $0.145^{*}$ & 0.113 & $0.166^{*}$ & $0.234^{* *}$ & -0.013 \\
\hline
\end{tabular}

Table 3. Correlation values for microbial parameters from Microscale Time Series $2(\mathrm{M} 2)$. All values $=$ Kendall's coefficient of rank correlation, $\tau .{ }^{*}$ : significance at the 0.05 level, $^{* *}$ : significance at the 0.01 level. LDNA: low DNA, HDNA: high DNA

\begin{tabular}{|lccccc|}
\hline & LDNA & HDNA(I) & HDNA(II) & Total bacteria \%HDNA \\
\hline LDNA & & & & & \\
HDNA(I) & $-0.164^{*}$ & & & & \\
HDNA(II) & -0.081 & $0.612^{* *}$ & & & \\
Total Bacteria & $0.149^{*}$ & $0.646^{* *}$ & $0.696^{* *}$ & & \\
\%HDNA & $-0.704^{* *}$ & $0.451^{* *}$ & $0.357^{* *}$ & $0.146^{*}$ & \\
Synechococcus & -0.111 & $0.412^{* *}$ & $0.405^{* *}$ & $0.376^{* *}$ & $0.253^{* *}$ \\
\hline
\end{tabular}

\section{DISCUSSION}

\section{Small-scale temporal variability in heterotrophic bacteria}

The temporal variability in the abundance of the total bacterial community observed during the smallscale study was primarily driven by increases in the HDNA populations, as no significant increasing trend was observed for the LDNA population. This is consistent with previous studies that observed highly dynamic HDNA populations associated with relatively invariable pools of LDNA cells (Gasol et al. 1999, Yanada et al. 2000). As a consequence, the proportion of HDNA cells within the bacterial community also exhibited a significant increase during the sampling period. This implies a gradual increase in the average activity levels of the bacterioplankton community throughout the day (Gasol et al. 1999, Lebaron et al. 2001).

Significant diel and small-scale (minutes to hours) temporal changes in bacterioplankton communities have been observed (Riemann et al. 1984, Fuhrman et al. 1985, Torréton et al. 1994, Gasol et al. 1998, Shiah 1999, Hagström et al. 2001), and the increases in bacterial abundance and activity displayed during the late 
afternoon here are congruent to patterns observed elsewhere (Marcussen 1984, Riemann et al. 1984, Gasol et al. 1998). Increases in bacterial growth during the daylight hours implies a coupling to the phytoplankton community, which relies on daily light cycles for photosynthetic production (Fuhrman et al. 1985). In the current study, increases in bacterial abundance
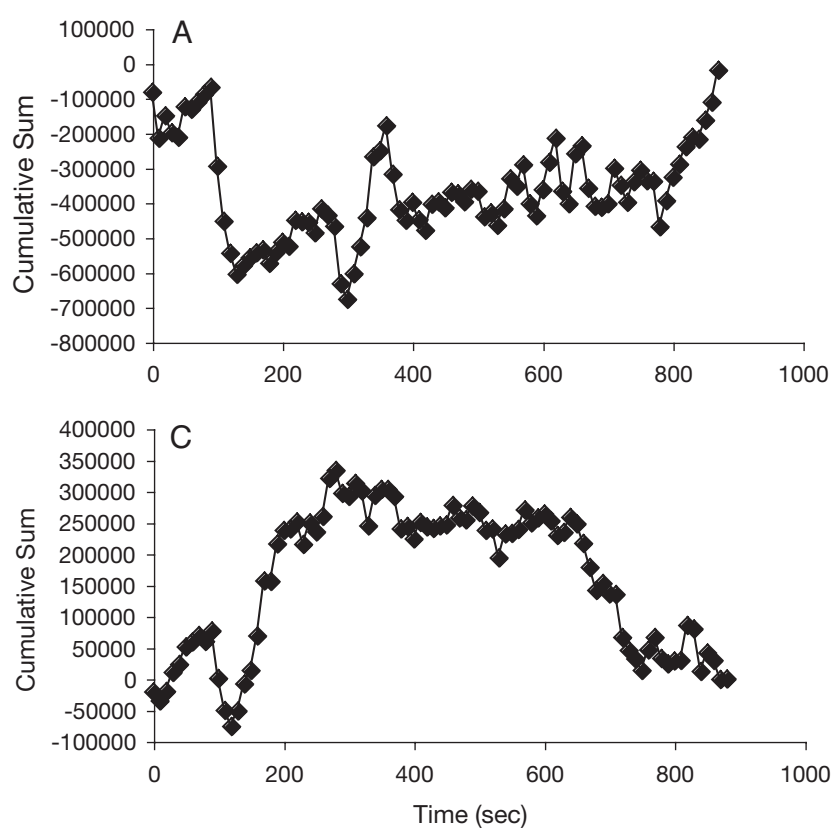

observed during the afternoon were indeed found to mirror an increase in chlorophyll a levels observed in a parallel study conducted at the Pt. Noarlunga site (L. Seuront \& M. Doubell unpubl. data). This may imply a coupling between the bacterioplankton and phytoplankton communities within the Pt. Noarlunga habitat. However, short-term changes in the abundance
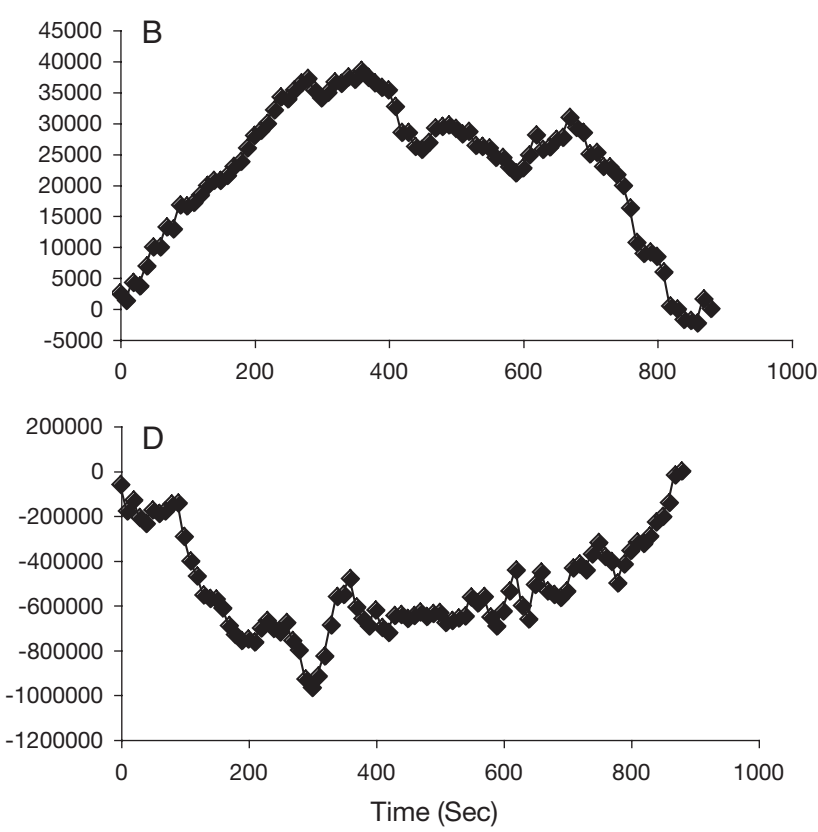

Fig. 7. Cumulative sum plots for Microscale Temporal Study 1 (M1) data. (A) Total bacteria, (B) Synechococcus cell counts, (C) low DNA, (D) high DNA
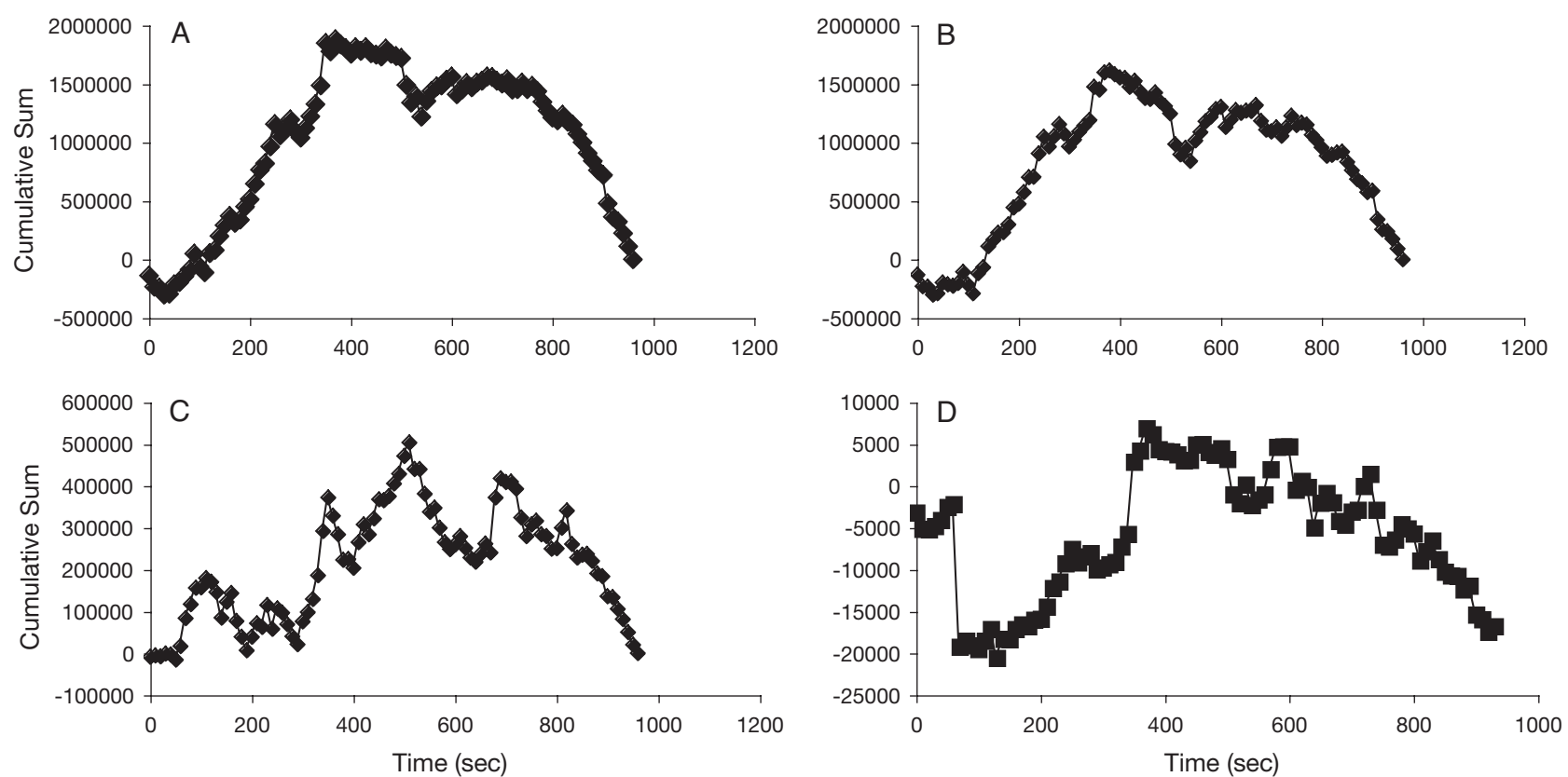

Fig. 8. Cumulative sum plots for Microscale Temporal Study 2 (M2) data. (A) Total bacteria, (B) high DNA, (C) low DNA, (D) Synechococcus cell counts 
and activity of bacterial communities have also been attributed to a number of other biological processes, including nutrient pulses (Hagström et al. 2001), periodicity in bacterivory (Wikner et al. 1990, Psenner \& Sommaruga 1992), DOM release from zooplankton grazing (Peduzzi \& Herndl 1992, Torréton et al. 1994), the influence of solar radiation (Chróst \& Faust 1999), and changes in viral lysis rates (Weinbauer et al. 1995, Bettarel et al. 2002).

Physical processes, including tidal fluctuations and wind-induced mixing, also influence bacterioplankton communities over short time periods within coastal habitats (Troussellier et al. 1993, Painchaud et al. 1995, Shiah \& Ducklow 1995, Torréton \& Dufour 1996). Here, bacterial abundance was positively correlated to turbulence intensity, with increases in bacterial biomass occurring during and after high tide in the late afternoon, when waves freely washed over the Pt. Noarlunga reef. Interestingly, while bacterial abundance increased during this period, changes in bacterial activity (percentage of HDNA cells) were not correlated to turbulence levels. Torréton \& Dufour (1996) observed similar associations between wind speed and bacterial communities within an atoll lagoon and suggested that increases in bacterial abundance without concomitant increases in activity may be explained by the resuspension of sediments. Due to the shallow water column and high levels of turbulence experienced in the present study, resuspension remains a possible mechanism for the increases in bacterial abundance observed (Wainwright 1990). Alternatively, as the dominant direction of water flow measured using the ADV was in a shoreward direction during high tide, advection of bacterial communities from the waters outside of the reef, or overlaying the reef, into the sampling site may have also led to the increased bacterial biomass during this period.

Given the rich macrophyte population covering the Pt. Noarlunga reef (Cheshire et al. 1999), the shallow waters overlying the reef are likely to accommodate a dense and active bacterial community (Delille \& Perret 1991). Indeed, during subsequent sampling conducted at the Pt. Noarlunga site, concentrations of bacteria in the waters overlying the reef were found to be over $30 \%$ higher than within the lagoon (J. R. Seymour et al. unpubl. results). The partial transfer of this water mass, or the advection of bacterial communities from outside the reef, into the lagoon could therefore have contributed to the increase in bacterial abundance observed during the afternoon.

A complex milieu of physical and biological forces shape short-term growth and loss processes within aquatic bacterial communities. The patterns observed here provide evidence for the potential importance of both physical (turbulence) and biological (chlorophyll levels) parameters in structuring bacterioplankton dynamics over the course of a few hours. Short-term increases in bacterial activity and abundance of this type are predicted to greatly and rapidly influence the cycling of organic materials in coastal waters (MeyerReil et al. 1979).

\section{Small-scale temporal variability in Synechococcus}

While coupling between heterotrophic bacteria and Synechococcus populations has been observed over short time scales elsewhere (Jacquet et al. 1998), there was no significant correlation between bacterioplankton and Synechococcus populations observed during this study. The Synechococcus population displayed distinct temporal patterns of its own, in both abundance and cellular parameters.

Synechococcus populations exhibit highly synchronised diel patterns in photosynthesis, cell growth and cell division that have been attributed to both daily light cycles (Vaulot et al. 1996, Jacquet et al. 1998, 2001) and a circadian rhythm (Sweeney \& Borgese 1989, Johnson et al. 1996). In this study Synechococcus cell abundance decreased throughout the morning until mid-afternoon, and then began to increase in the late afternoon and early evening. Cell forward-angle light scatter (FSC), which is correlated to phytoplankton cell size (Cunningham \& Buonaccorsi 1992), increased from early morning until early evening. The decreases in mean cell size and concomitant increase in cell abundance observed here close to dusk is indicative of cell division occurring during this period and follows a daily pattern that is apparently universal for Synechococcus communities across systems (Vaulot et al. 1996, Jacquet et al. 1998, 2001, 2002, Vaulot \& Marie 1999).

Unlike the heterotrophic bacterial community, there was no correlation between the Synechococcus population and levels of turbulent kinetic energy dissipation. This is consistent with the findings of Jacquet et al. (2002) who showed that strong hydrological variability had little influence on Synechococcus cell cycles.

Cell loss processes amongst Synechococcus communities are driven by grazing by heterotrophic nanoflagellates (Dolan \& Šimek 1999) and viral infection (Suttle \& Chan 1994). Short-term variations in cell concentrations, like those observed here, indicate that loss processes do not occur at a uniform rate (Vaulot \& Marie 1999). Grazing rates by heterotrophic nanoflagellates indeed vary with time of day and stage of Synechococcus cell cycle (Christoffersen 1994, Dolan \& Šimek 1999, Christaki et al. 2002), and viral infection rates can also exhibit diel variability (Weinbauer et al. 1995). If the biomass of the Synechococcus community is controlled by short-term rhythms in grazing or viral 
activity, then heterotrophic bacteria may experience intermittent pulses of increased DOM in the form of grazer excreta or viral lysate (Dolan \& Šimek 1999). It is noteworthy that during this study bacterial activity and abundance increased following a significant decline in Synechococcus abundance, suggesting an indirect coupling between the 2 communities over short time scales.

\section{Microscale temporal variability amongst microbial populations}

Microscale spatial structure and variability in the abundance, activity and composition of bacterial and phytoplankton communities have been widely illustrated (Mitchell \& Fuhrman 1989, Seymour et al. 2000, 2004, Long \& Azam 2001, Waters et al. 2003). However, only a few studies have investigated temporal variability over periods of seconds to minutes in natural environments. Of those that have, intense shifts in viral abundance (Bratbak et al. 1996) and nutrients (Seuront et al. 2002) have been shown to occur over time periods of seconds to minutes.

Microscale temporal measurements can be directly related to compatible length scales (Taylor 1938), and we calculated that the temporal resolution of $10 \mathrm{~s}$ employed here was equivalent to spatial resolutions of $61 \mathrm{~cm}$ and $2.3 \mathrm{~m}$ in the 2 microscale studies conducted. In this specific case, however, due to the small sample volumes and the expectation that volumes of this size may represent fundamentally different biological and physical microenvironments (Azam 1998, Long \& Azam 2001, Seuront 2001), we suggest that these subsamples could alternatively be viewed as discrete volumes or microenvironments rather than length or time-series measurements. Consequently, the highly intermittent patterns observed in the microscale studies are likely to have been generated by the interactions between organisms and a heterogenous microhabitat, where distinct microenvironments facilitate increased levels of microbial abundance, diversity and activity (Azam 1998, Long \& Azam 2001).

Microscale variability in the availability of dissolved and particulate organic and inorganic nutrients is predicted to be a common feature of the marine environment, creating heterogeneity in the distribution and composition of autotrophic and heterotrophic microorganisms (Lehman \& Scavia 1982, Azam \& Ammerman 1984, Mitchell et al. 1985, Blackburn et al. 1997, 1998, Azam 1998, Blackburn \& Fenchel 1999, Kiørboe \& Jackson 2001). In particular, suspended and sinking organic particles represent localised microhabitats for microbial assemblages (Lampitt et al. 1993, Alldredge et al. 1996, Azam 1998, Ploug et al. 1999), with concen- trations of attached heterotrophic bacteria and cyanobacteria several orders of magnitude higher on organic aggregates than in the surrounding water (Lampitt et al. 1993, Grossart et al. 2003). Mitchell \& Fuhrman (1989) suggested that the single-point abundance peaks of bacteria that they regularly observed during microscale sampling were probably generated by the collection of organic aggregates, and due to the small sample volumes used in this study, even moderately enriched particles could be responsible for the hotspots of microbial abundance and activity observed here.

While the most dominant features of the microscale time series were often discrete hotspots and coldspots, cumulative sums analysis also revealed underlying patterns and trends in both microscale studies, characterised by discrete regions of positive or negative slope, indicative of successive values above or below the global mean. These coherent trends sometimes extended over periods of up to 5 to $7 \mathrm{~min}$ and may indicate the existence of small-scale (m) patches of organisms. The mechanisms generating these patterns are not straightforward, but the dissimilar extent of coupling between the cumulative sums of different populations observed between the 2 microscale studies may indicate a role of turbulence. In M1, where turbulence levels were low, the cumulative sums of the bacteria and Synechococcus populations, as well as the HDNA and LDNA populations, were significantly dissimilar. In $\mathrm{M} 2$, where turbulence levels were high, all populations exhibited significantly similar cumulative sum plots. Turbulent forcing is predicted to strongly influence small-scale patterns and processes in the ocean (Rothschild \& Osborn 1988, Squires \& Yamazaki 1995, Jimenez 1997, Kiørboe 1997, Seuront et al. 2001), and close coupling between turbulent mixing and smallscale spatial variations in the abundance of bacteria has been observed (Andreatta et al. 2004). While it is difficult to predict the extent to which physical processes directly influenced the patterns observed here, the temporal variability and patterns observed here indicate that processes operating on time scales of seconds to minutes can exert significant control over the abundance and activity of planktonic microbial communities in the ocean.

\section{Small-scale versus microscale variability}

In this study we have identified variability in the abundance and cellular characteristics of a coastal microbial community at different temporal scales. The absolute changes in abundance of the bacterial community observed during the 16 min sampling periods were comparable to the variation observed over the 
course of the $11 \mathrm{~h}$ study period. Shifts in the activity of the heterotrophic bacterial community and the abundance of Synechococcus were actually slightly greater at the smaller temporal scale. However, the patterns observed, and the nature of this variability, were fundamentally different between the 2 temporal scales.

Over the course of the $11 \mathrm{~h}$ small-scale study, variability was expressed in the form of coherent trends that were highly comparable to the patterns previously observed in diel studies (Riemann et al. 1984, Vaulot et al. 1996, Gasol et al. 1998, Jacquet et al. 1998, 2001). Alternatively, the microscale time series were characterised by intermittent and spikey patterns, often consisting of discrete hotspots of abundance. Consequently, while the range of the variability was similar between the small-scale and microscale studies, the extent of variance at each scale was dissimilar, due to the absence of strong high and low peaks in the smallscale study. The high and low peaks driving the variability in the microscale experiments were relatively infrequent and therefore rarely encountered during the low-frequency sampling conducted in the smallscale study.

The characteristic nature of the different patterns observed here is a manifestation of the dissimilar generating mechanisms operating at the different scales studied. These differences were further demonstrated by the dissimilar cumulative sum plots observed in the small-scale and microscale studies. In the small-scale study the cumulative sums were characterised by relatively smooth and distinct periods, while the microscale patterns were largely characterised by fluctuations indicative of more localised processes.

Relationships between the different microbial populations studied here were also found to be quite dissimilar between the different temporal scales. The temporal patterns of the heterotrophic bacteria and Synechococcus populations were not correlated during the small-scale study but were shown to be significantly correlated in both of the microscale studies, implying an inherently different relationship between the 2 communities at the different temporal scales. We also found that the LDNA population was relatively invariable during the small-scale study, as is predicted by the assumption that this group represents dead or dormant cells (Jellett et al. 1996, Gasol et al. 1999, Lebaron et al. 2001) but actually exhibited higher levels of variability than the HDNA population in both of the microscale studies. The cause of this unexpected variability within the LDNA population is not clear, but this pattern of apparent variability at one scale and not another once again indicates that intrinsically different processes and controls appear to have been operating at the different temporal scales investigated here.

\section{Implications}

Biological and physical variability in the oceans occurs simultaneously on different time and space scales (Ducklow 1984, Dickey 1991), and our results clearly represent a manifestation of this complexity. We observed dissimilar patterns at the different temporal scales investigated here, implying that fundamentally different forcing mechanisms and ecological interactions dominated at each scale. An appreciation of the processes occurring over the short time frames investigated here is important to our understanding of marine microbial communities because (1) events of major ecological significance often result from sporadic and short-lived environmental perturbations (Taylor \& Howes 1994) and (2) the time frames of relevance to the life history of marine microorganisms are relatively short. Often, particularly in large-scale studies, the intermittent patterns observed at smaller scales may be interpreted as of little ecological importance and 'averaged out'. However, we argue that this smallscale and microscale variability will often have an ecological relevance that is equivalent to, or greater than, the changes observed at larger scales. For instance, microscale intermittency in prey density will have a definitive effect on the grazing efficiency and growth and survival of planktonic predators (Rothschild 1992), subsequently influencing the flow of carbon through the microbial loop (Azam et al. 1983).

Likewise, small-scale shifts in microbial activity will lead to localised biogeochemical cycling, which could have critical implications for calculations of bulk processes, because specific microzones or 'hotspots', where microbial activity and production significantly exceed background levels, may be missed by bulk analysis techniques (Azam 1998). Indeed it has been recognised for several years that large volume samples may lead to underestimates of productivity due to the inadequate sampling of discrete microzones (Knauer et al. 1982), and that even if one is interested in largescale patterns and processes, samples should be taken at smaller intervals, otherwise a misleading picture may be obtained (Gocke et al. 1987, Taylor \& Howes 1994, Karl et al. 2003). We further stress that an understanding of the dynamics occurring at small scales is vital not only for an appreciation of the ecology of the microorganisms whose lives are defined on the basis of these spatio-temporal scales but for the phenomenology of entire aquatic ecosystems.

Acknowledgements. S. Bailey provided valuable technical assistance with flow cytometry. N. Patten and M. Doubell assisted with the field sampling. Three anonymous reviewers provided helpful comments on the manuscript. Funding for this research was provided by the Australian Research 
Council and the Flinders University of South Australia. The Flinders University of South Australia provided a postgraduate research scholarship to J.R.S. and a visiting scientist fellowship to L.S.

\section{LITERATURE CITED}

Alldredge AL, Cole JJ, Caron DA (1986) Production of heterotrophic bacteria inhabiting macroscopic organic aggregates (marine snow) from surface waters. Limnol Oceanogr 31:68-78

Andreatta S, Wallinger MM, Piera J, Catalan J, Psenner R, Hofer JS, Sommaruga R (2004) Tools for discrimination and analysis of lake bacterioplankton subgroups measured by flow cytometry in a high-resolution depth profile. Aquat Microb Ecol 36:107-115

Azam F (1998) Microbial control of oceanic carbon flux: the plot thickens. Science 280:694-696

Azam F, Ammerman JW (1984) Cycling of organic matter by bacterioplankton in pelagic marine ecosystems: microenvironmental considerations. In: Fasham MJR (ed) Flows of energy and materials in marine ecosystems. Plenum Press, New York, p 345-360

Azam F, Fenchel T, Field JG, Gray JS, Meyer-Reil LA, Thingstad F (1983) The ecological role of water-column microbes in the sea. Mar Ecol Prog Ser 10:257-263

Beaugrand G, Ibañez F, Reid PC (2000) Spatial, seasonal and long-term fluctuations of plankton in relation to hydroclimatic features in the English Channel, Celtic Sea and Bay of Biscay. Mar Ecol Prog Ser 200:93-102

Bettarel Y, Sime NT, Amblard C, Carrias JF, Sargos D, Garabetian F, Lavandier P (2002) The functional importance of bacteriophages in the microbial loop of an oligomesotrophic lake over a diel cycle. Ann Limnol 38:263-269

Bidle KD, Azam F (1999) Accelerated dissolution of diatom silica by marine bacterial assemblages. Nature 397:508-512

Blackburn N, Fenchel T (1999) Influence of bacteria, diffusion and shear on micro-scale nutrient patches, and implications for bacterial chemotaxis. Mar Ecol Prog Ser 189:1-7

Blackburn N, Azam F, Hagström Å (1997) Spatially explicit simulations of a microbial food web. Limnol Oceanogr 42 : 613-622

Blackburn N, Fenchel T, Mitchell JG (1998) Microscale nutrient patches in plankton habitats shown by chemotactic bacteria. Science 282:2254-2256

Bratbak G, Heldal M, Thingstad TF, Tuomi P (1996) Dynamics of virus abundance in coastal seawater. FEMS Microbiol Ecol 19:263-269

Cheshire AC, Miller DJ, Stewart R (1999) Effect of dispersed sediment plumes from beach sand replenishment dredging on recruitment of Phaeophycean algae to rocky reefs in Gulf St. Vincent, South Australia. Report to the Coast and Marine Section, Environment Protection Authority of South Australia, Adelaide

Christaki U, Courties C, Karayanni H, Giannakourou A, Maravelias C, Kormas KA, Lebaron P (2002) Dynamic characteristics of Procholorococcus and Synechococcus consumption by bactivorous nanoflagellates. Microb Ecol 43: 341-352

Christoffersen K (1994) Variations of feeding activities of heterotrophic nanoflagellates on picoplankton. Mar Microb Food Webs 8:111-123

Chróst RJ, Faust MA (1999) Consequences of solar radiation on bacterial secondary production and growth rates in subtropical coastal water (Atlantic Coral Reef off Belize, Central America). Aquat Microb Ecol 20:39-48
Cunningham A, Buonassorsi GA (1992) Narrow angle forward light scattering from individual algal cells: implications for size and shape discrimination in flow cytometry. J Plankton Res 14:223-234

del Giorgio PA, Scarborough G (1995) Increase in the proportion of metabolically active bacteria along gradients of enrichment in freshwater and marine plankton: implications for estimates of bacterial growth and production rates. J Plankton Res 17:1905-1924

Delille D, Perret E (1991) The influence of giant kelp Macrocystis pyrifera on the growth of subantarctic marine bacteria. J Exp Mar Biol Ecol 153:227-239

Denman KL, Gargett AE (1995) Biological-physical interactions in the upper ocean: the role of vertical and small scale transport processes. Annu Rev Fluid Mech 27: $225-255$

Dickey TD (1991) The emergence of concurrent highresolution physical and bio-optical measurements in the upper ocean and their applications. Rev Geophys 29: $383-413$

Dolan JR, Šimek K (1999) Diel periodicity in Synechococcus populations and grazing by heterotrophic nanoflagellates: analysis of food vacuole contents. Limnol Oceanogr 44: 1565-1570

Ducklow HW (1984) Geographical ecology of marine bacteria: physical and biological variability at the mesoscale. In: King MJ, Reddy CA (eds) Current perspectives in microbial ecology. American Society for Microbiology, Washington, DC, p 22-32

Fuhrman JA, Eppley RW, Hagström Å, Azam F (1985) Diel variations in bacterioplankton, phytoplankton, and related parameters in the Southern California Bight. Mar Ecol Prog Ser 27:9-20

Gasol JM, del Giorgio PA (2000) Using flow cytometry for counting natural planktonic bacteria and understanding the structure of planktonic bacterial communities. Sci Mar 64(2):197-224

Gasol JM, Doval MD, Pinhassi J, Calderón-Paz JI, GuixaBoixareu N, Vaqué D, Pedrós-Alió C (1998) Diel variations in bacterial heterotrophic activity and growth in the northwestern Mediterranean Sea. Mar Ecol Prog Ser 164: $107-124$

Gasol JM, Zweifel UL, Peters F, Fuhrman JA, Hagström Å (1999) Significance of size and nucleic acid content heterogeneity as measured by flow cytometry in natural planktonic bacteria. Appl Environ Microbiol 65: 4475-4483

Gocke K, Kremling K, Osterroht C, Wnck A (1987) Short-term fluctuations of microbial and chemical variables during different seasons in coastal Baltic waters. Mar Ecol Prog Ser 40:137-144

Grossart HP, Hietanen S, Ploug H (2003) Microbial dynamics on diatom aggregates in Øresund, Denmark. Mar Ecol Prog Ser 249:69-78

Hagström Å, Pinhassi J, Zweifel UL (2001) Marine bacterioplankton show bursts of rapid growth induced by substrate shifts. Aquat Microb Ecol 24:109-115

Ibañez F, Fromentin JM, Castel J (1993) Application de la méthode des sommes cumulées à l'analyse des séries chronologiques en océanographie. Cr Acad Sci Paris (Sci Vie) 316:745-748

Jacquet S, Lennon JF, Marie D, Vaulot D (1998) Picoplankton population dynamics in coastal waters of the northwestern Mediterranean Sea. Limnol Oceanogr 43:1916-1931

Jacquet S, Partensky F, Lenon JF, Vaulot D (2001) Diel patterns of growth and division in marine picoplankton in culture. J Phycol 37:357-369 
Jacquet S, Prieur L, Avois-Jacquet C, Lennon JF, Vaulot D (2002) Short-timescale variability of picoplankton abundance and cellular parameters in surface waters of the Alboran Sea (western Mediterranean). J Plankton Res 24: 635-651

Jellett JF, Li WKW, Dickie PM, Boraie A, Kepkay PE (1996) Metabolic activity of bacterioplankton communities assessed by flow cytometry and single carbon substrate utilisation. Mar Ecol Prog Ser 136:213-225

Jimenez J (1997) Oceanic turbulence at millimetre scales. Sci Mar 61:47-56

Johnson CH, Golden SS, Ishiura M, Kondo T (1996) Circadian clocks in prokaryotes. Mol Microbiol 21:5-11

Karl DM, Laws EA, Morris P, Williams PJL, Emerson S (2003) Metabolic balance of the open sea. Nature 426:32

Kendall MG, Stuart A (1966) The advanced theory of statistics, Vol 3. Hafner, New York

Kiørboe T (1997) Small-scale turbulence, marine snow formation, and planktivorous feeding. Sci Mar 61:141-158

Kiørboe T, Jackson GA (2001) Marine snow, organic solute plumes, and optimal chemosensory behaviour of bacteria. Limnol Oceanogr 46:1309-1318

Knauer GA, Hebel D, Cipriano F (1982) Marine snow: a major site of primary production in coastal waters. Nature 300 : 630-631

Lampitt RS, Wishner KF, Turley CM, Angel MV (1993) Marine snow studies in the Northeast Atlantic Ocean: distribution, composition and role as a food source for migrating plankton. Mar Biol 116:689-702

Lebaron P, Servais P, Agogué H, Courties C, Joux F (2001) Does the high nucleic acid content of individual bacterial cells allow us to discriminate between active cells and inactive cells in aquatic systems? Appl Environ Microb 67 (4):1775-1782

Lebaron P, Servais P, Baudox AC, Bourrain M, Courties C, Parthuisot N (2002) Variations of bacterial specific activity with cell size and nucleic acid content assessed by flow cytometry. Aquat Microb Ecol 28:131-140

Le Fevre-Lehoerff G, Ibañez F, Poniz P, Fromentin JM (1995) Hydroclimatic relationships with planktonic time series from 1975 to 1992 in the North Sea off Gravelines, France. Mar Ecol Prog Ser 129:269-281

Lehman JT, Scavia D (1982) Microscale patchiness of nutrients in plankton communities. Science 216:729-730

Li WKW, Jellet JF, Dickie PM (1995) DNA distributions in planktonic bacteria stained with TOTO or TO-PRO. Limnol Oceanogr 40:1485-1495

Long RA, Azam F (2001) Microscale patchiness of bacterioplankton assemblage richness in seawater. Aquat Microb Ecol 26:103-113

Manly BF, Mackenzie D (2000) A cumulative sum type of method for environmental monitoring. Environmetrics 11: 151-166

Marcussen B, Nielsen P, Jeppesen M (1984) Diel changes in bacterial activity determined by means of microautoradiography. Arch Hydrobiol 19:141-149

Marie D, Partensky F, Jacquet S, Vaulot D (1997) Enumeration and cell cycle analysis of natural populations of marine picoplankton by flow cytometry using a novel nucleic acid dye. Appl Environ Microbiol 63:186-193

Marie D, Partensky F, Vaulot D, Brussard C (1999) Enumeration of phytoplankton, bacteria and viruses in marine samples. Curr Protocols Cytom 11.11.1-11.11.15

Marrasé C, Saiz E, Redondo JM (1997) Lectures on plankton and turbulence. Sci Mar 61(Suppl 1)

Meyer-Reil LA, Bölter M, Liebezeit G, Schramm W (1979) Short-term variations in microbiological and chemical parameters. Mar Ecol Prog Ser 1:1-6

Mitchell JG, Okubo A, Fuhrman JA (1985) Microzones surrounding phytoplankton form the basis for a stratified marine microbial ecosystem. Nature 316(6023):58-59

Mitchell JG, Fuhrman JA (1989) Centimeter scale vertical heterogeneity in bacteria and chlorophyll a. Mar Ecol Prog Ser 54:141-148

Nicholls KH (1997) Planktonic green algae in western Lake Erie: the importance of temporal scale in the interpretation of change. Freshw Biol 38:419-425

Okubo A, Mitchell JG (2001) Patchy distribution and diffusion. In: Okubo, Levin SA (eds) Diffusion and ecological problems: modern perspectives, 2nd edn. Springer, New York

Painchaud J, Lefaivre D, Therriault JC, Legendre L (1995) Physical processes controlling bacterial distribution in the upper St Lawrence Estuary. Estuaries 18:433-444

Peduzzi P, Herndl GJ (1992) Zooplankton activity fuelling the microbial loop: differential growth response of bacteria from oligotrophic and eutrophic waters. Limnol Oceanogr 37:1087-1092

Ploug H, Grossart HP, Azam, F, Jørgensen BB (1999) Photosynthesis, respiration, and carbon turnover in sinking marine snow from surface waters of Southern California Bight: implications for the carbon cycle in the ocean. Mar Ecol Prog Ser 179:1-11

Psenner R, Sommaruga R (1992) Are rapid changes in bacterial biomass caused by shifts from top-down to bottom-up control? Limnol Oceanogr 37:1092-1100

Riemann B, Nielsen P, Jeppesen M, Marcussen B, Fuhrman JA (1984) Diel changes in bacterial biomass and growth rates in coastal environments, determined by means of thymidine incorporation into DNA, frequency of dividing cells (FDC), and microautoradiography. Mar Ecol Prog Ser $17: 227-235$

Rothschild BJ (1992) Application of stochastic geometry to problems in plankton ecology. Phil Trans R Soc Lond B 336:225-237

Rothschild BJ, Osborn TR (1988) Small scale turbulence and plankton contact rates. J Plankton Res 10:465-474

Servais P, Casamayor EO, Courties C, Catala P, Parthuisot N, Lebaron P (2003) Activity and diversity of bacterial cells with high and low nucleic acid content. Aquat Microb Ecol 33:41-51

Seuront L (2001) Microscale processes in the ocean: why are they so important for ecosystem functioning? La Mer 39: 1-8

Seuront L, Schmitt FG (2001) Describing intermittent processes in the ocean-univariate and bivariate multiscaling procedures. In: Muller P, Garrett C (eds) Stirring and mixing in a stratified ocean. Proceedings of the Aha Huliko'a Hawaiian Winter Workshop. SOEST, University of Hawaii, Honolulu, p 29-144

Seuront L, Schmitt FG (2003) A unifying topological framework to deal with scales, intensity and unusual extreme events in biological time series. CIESM Workshop Monographs 22:43-48

Seuront L, Schmitt F, Lagadeuc Y, Schertzer D, Lovejoy S (1999) Universal multifractal analysis as a tool to characterize multiscale intermittent patterns: example of phytoplankton distribution in turbulent coastal waters. J Plankton Res 21:877-922

Seuront L, Schmitt F, Lagadeuc Y (2001) Turbulence intermittency, small-scale phytoplankton patchiness and encounter rates in plankton: where do we go from here? Deep-Sea Res I 48:1199-1215

Seuront L, Gentilhomme V, Lagadeuc Y (2002) Small-scale 
nutrient patches in tidally mixed coastal waters. Mar Ecol Prog Ser 232:29-44

Seymour JR, Mitchell JG, Pearson L, Waters R (2000) Heterogeneity in bacterioplankton abundance from 4.5 millimetre resolution sampling. Aquat Microb Ecol 22:143-153

Seymour JR, Mitchell JG, Seuront L (2004) Microscale heterogeneity in the activity of coastal bacterioplankton communities. Aquat Microb Ecol 35:1-16

Shiah FK (1999) Diel cycles of heterotrophic bacterioplankton abundance and production in the ocean surface waters. Aquat Microb Ecol 17:239-246

Shiah FK, Ducklow HW (1995) Mulitscale variability in bacterioplankton abundance, production, and specific growth rate in a temperate salt-marsh tidal creek. Limnol Oceanogr 40:55-66

Simon M (1994) Diel variability of bacterioplankton biomass production and cell multiplication in Lake Constance. Arch Hydrobiol 130:283-302

Sokal RR, Rohlf FJ (1995) Biometry, 3rd edn. WH Freeman, San Francisco, CA

Squires KD, Yamazaki H (1995) Preferential concentration of marine particles in isotropic turbulence. Deep Sea Res 42: 1989-2004

Suttle CA, Chan AM (1994) Dynamics and distribution of cyanophages and their effect on marine Synechococcus spp. Appl Environ Microbiol 60:3167-3174

Sweeney BM, Borgese MB (1989) A circadian rhythm in cell division in a prokaryote, the cyanobacterium Synechococcus WH7803. J Phycol 25:183-186

Taylor CD, Howes BL (1994) Effect of sampling frequency on measurements of seasonal primary production and oxygen status in near shore coastal ecosystems. Mar Ecol Prog Ser 108:193-203

Taylor GI (1938) The spectrum of turbulence. Proc R Soc Lond A 20:1167-1170

Tennekes H, Lumley JL (1972) A first course in turbulence. MIT Press, Cambridge, MA

Torréton JP, Bouvy M, Arfi R (1994) Diel fluctuations of bacterial abundance and productivity in a shallow eutrophic tropical lagoon. Arch Hydrobiol 131:79-92

Editorial responsibility: Otto Kinne (Editor-in-Chief), Oldendorf/Luhe, Germany
Torréton JP, Dufour P (1996) Temporal and spatial stability of bacterioplankton biomass and productivity in an atoll lagoon. Aquat Microb Ecol 11:251-261

Troussellier M, Cahet G, Lebaron P, Baleux B (1993) Distribution and dynamics of bacterial production in relation to wind perturbations in a Mediterranean lagoon. Limnol Oceanogr 38:193-201

Vaulot D (1989) CytoPC: processing software for flow cytometric data. Signal Noise 2:8

Vaulot D, Marie D (1999) Diel variability of photosynthetic picoplankton in the equatorial Pacific. J Geophys Res 104: 3297-3310

Vaulot D, LeBot N, Marie D, Fukai E (1996) Effect of phosphorus on the Synechococcus cell cycle in surface Mediterranean waters during summer. Appl Environ Microbiol 62: $2527-2533$

Wainwright SC (1990) Sediment-to-water fluxes of particulate material and microbes by resuspension and their contribution to the planktonic food web. Mar Ecol Prog Ser 62: 271-281

Waters RL, Mitchell JG, Seymour JR (2003) Geostatistical characterisation of centimetre-scale spatial structure of in vivo fluorescence. Mar Ecol Prog Ser 251:49-58

Weinbauer MG, Fuks D, Puskaric S, Peduzzi P (1995) Diel, seasonal, and depth-related variability of viruses and dissolved DNA in the northern Adriatic Sea. Microb Ecol 30: $25-41$

Wikner J, Hagström $\AA$ (1991) Annual study of bacterioplankton community dynamics. Limnol Oceanogr 36: 1313-1324

Wikner J, Rassoulzadegan F, Hagström Å (1990) Periodic bacterivore activity balances bacterial growth in the marine environment. Limnol Oceanogr 35:313-324

Wolk F, Seuront L, Yamazaki H (2001) Spatial resolution of a new micro-optical probe for chlorophyll and turbidity. J Tokyo Univ Fish 87:13

Yanada M, Yokokawa T, Weng Lee C, Tanak H, Kudo I, Maita Y (2000) Seasonal variation of 2 different heterotrophic bacterial assemblages in subarctic coastal seawater. Mar Ecol Prog Ser 204:289-292

Submitted: October 1, 2004; Accepted: May 11, 2005

Proofs received from author(s): August 19, 2005 